\title{
A Macro and Micro Perspective Issue in Globalization
}

\author{
Leila Kamelifar \\ Refah Humanitarian Science Faculty \\ Mardom St., Baharestan Sq., Tehran, Iran
}

Tel: 912-514-4930Ｅ-mail: leilakamelifar@yahoo.cm

Sepideh Mirzaee

Imam Reza International University

Mashhad, Iran

Tel: 915-519-9378Ｅ-mail: spdmirzaee@gmail.com

Received: August 5, 2017 Accepted: August 24, 2017 Published: August 25, 2017

doi:10.5296/jsel.v5i1.11750 URL: https://doi.org/10.5296/jsel.v5i1.11750

\begin{abstract}
Globalization is a phenomenon that makes any country to contact with the whole world and China is not an exception. Globalization has a lot of cultural influences on all the countries over the world. This paper reviews the literature about the issue of globalization, politeness and politeness strategies used by Chinese English learners and their counterpart Native Americans. Furthermore, the present paper attempts to find the sources of these "cultural mismatches". This paper ends with the implications of this concept in the field of language learning and teaching.
\end{abstract}

Keywords: Globalization, Politeness, Politeness strategies 


\section{Introduction}

According to the research, many studies in discourse analysis indicate that the Chinese students have some problems in their communication with students from other countries. Chen (2001) relates these problems to the Chinese' lack of enough knowledge in the area of intercultural communication, and specifically difficulties in application of politeness strategies. Findings of these studies suggest that intercultural communication skills should be a vital element of English language teaching in China with the swift globalization of English and its use in business communication. Moreover, Chinese students have made the largest number of overseas students in the world (Yao 2004, cited in Lee, 2011). The reason is that they want to burgeon their communication skills through the interaction with foreigners or native peersLee (2011) contends that the politeness issue has received much attention in China in recent years. But it is important to know that regarding Chinese students and their politeness it seems a big gap between them and the Native American speakers.

\section{Literature Review}

Xiao and Petraki (2005) deal with difficulties Chinese encountered in real-life interactions with native speakers of English such as cultural shock and differences in nonverbal communication and politeness strategies.

Liu (2001) believes that Chinese students' silence in the classroom is because of Chinese perception of reputation. In his study, Liu discussed that although the silence patterns can sometimes lead to intercultural mis-understandings and stereotyping, the way Chinese students use politeness and face strategies should be treated with intercultural sensitivity and respect. He suggested that Chinese students should develop a new face-saving concept to better interact with other students and to adapt to the new community (Liu 2001, p.16).

Liao and Bresnahan (1996) discussed common types of cultural mistakes made by Chinese students. One of these cultural mistakes is incorporates the use of politeness and modesty strategies by negating any praise.

$\mathrm{Gu}(1990)$ is a leading figure in the study of Chinese politeness. He introduces four maxims on Chinese politeness. They are the self-denigration maxim (i.e. to denigrate self and to elevate the others), the address maxim, the generosity maxim and the tact maxim.

Furthermore, Liao and Bresnahan (1996) finds that significantly more Chinese students than their American peers use the address form again and again to replace the second person pronoun 'you' when they talk with a person of the higher status. It means that Chinese are more sensitive towards the notion of politeness in comparisons with Americans. Even if politeness is being considered the same, the Chinese students and American subjects show much difference in the application of contradictory statements and politeness strategies. The Chinese behave more sensitively to hierarchical status in applying politeness strategies. 


\subsection{What is Politeness?}

Politeness, as defined by Brown and Levinson, is the combination of both formal and functional features such as nominalize, passivize, use certain lexical items, give deference, be indirect, etc. which go with face-violating speech act, such as requesting in order to diminish its threat.

\subsection{How is Politeness Learnt by Chinese Children?}

Some studies compare differences in teaching politeness between Chinese and European parents.

Lee (2011, p. 13) claims that Chinese parents place a great emphasis on politeness, as it is evident in responses given by the Chinese learners themselves. Politeness and polite behavior are mainly taught verbally, through direct lecturing, and also by setting of various examples by parents themselves. It was also mentioned that negative examples were often observed and used as a point as to how not to behave. Seemingly, these responses would not highly differ with western methods of teaching children politeness. Lee (2011) believes that one remarkable difference between Chinese parents and western parents would be related to their approach towards punishment. Besides, schools are the second most important cause of education about politeness.

\subsection{Divergent Interpretation of Politeness}

The findings of different studies done by Carrel and Konneker (1981) show that there is a high correlation between native and nonnative perceptions and judgments of politeness. Axiomatically, English learners have little problems determining polite strategies. Their use (or non-use) of these strategies is a different story. However, understandings both Chinese and Native Americans regarding these politeness strategies are somehow the same. In fact the aim of Lee' (2011) study is to understand that by considering this fact that both Chinese and native Americans have the same perceptions of politeness strategies why there is a large gap between their understandings of politeness strategies and their production of those strategies. Both of these groups of learners judge politeness strategies likewise, but it is obvious that actual language production differs pretty noticeably when it comes to the level of verbal and linguistics.

Therefore, Lee (2011) shows that only having the similar perceptions about a definite phenomenon cannot warranty that real expression of these values will be the same.

Moreover, Morand (2003, p. 525) states, "Cross cultural communication involves more than comprehension of global, overarching value dimensions." Rather, what is crucial is that "one must understand how cultures differ relative to the patterning of face-to-face discourse - the actual behaviors, gestures, and nuances of expression exchanged by individuals as they interact."

Lee (2011) argues that as age progresses, the environment and the people around every individual, presents another tough source of power on the linguistic behavior of youths. 
Moreover about this issue is based on Ladegaard (2004)'s ideas which illustrate that children use the linguistic system which, in some specific context and settings find themselves in, is probable to give them most success in terms of being heard, getting their message across, and getting their way.

\subsection{The Importance of Politeness in China}

Politeness is an important part of culture which shapes human behavior within a society. Goode et al., (2000, p. 25) explain this politeness as an 'integrated pattern of human behavior that includes thoughts, communications, languages, practices, beliefs, values, customs, courtesies, rituals, manners of interacting and roles, relationships and expected behaviors of a racial, ethnic, religious or social group; and the ability to transmit the above to succeeding generations'. This view represents the importance of politeness in culture and politeness is represented in all the above human interactions, as a result politeness cannot be considered a separate isolated component of language learning. The spectrum of politeness affects all human behavior and interactions, therefore 'linguistic competence alone is not enough for learners of a language to be competent in that language' (Krasner, 1999). Language learners need to understand culture, context and politeness to be able to function and communicate appropriately in the target language.

\section{Conclusion}

Given the extent and complexity that enfolds cultural politeness in language teaching and learning, this paper has only considered some features of it. Politeness cannot be separated from culture and appropriate norms, this is a clear sign of the significance of cultural and context awareness in teaching and learning English. If the goal for language learning is communicative competence - the language learner can perform efficiently and properly in the target language- then culture and context awareness must play a key role in language teaching. Teaching culture in China, maybe in other countries, has usually aimed at a few lessons on western holidays such as Halloween, Thanksgiving and Christmas, food, hobbies and the like, but it is not enough. Though these maybe interesting for students, but polite appropriate communicative language means more than eating turkey at Christmas and remembering to say thank you for a gift. It means understanding proper behavior in a given situation, and knowing what is appropriate to say to whom. Day-to-day appropriate communicative norms must be understood by the learners. Therefore language teaching must implement a holistic approach to culture, context and propriety. Every aspect of language interaction that is taught must incorporate culture, context and polite appropriate language awareness in a none-intrusive manner. Language teachers training must address and include the necessity of culture, context and appropriate language awareness in the acquisition of communicative competence. Instead of the idea of culture as a separate entity to language competence, culture should be an integrated and a constant part of language teaching and learning. Polite communication will not be gained unless linguistic theory which plays an important role in teaching ideology and methodology stress the role of culture and context in English language learning and teaching. Teacher ability and understanding of language teaching and learning must be improved to a 
higher level of competence in China for communicative competence to be realized.

\section{References}

Carrel, P. L., \& Konneker, B. H. (1981). Politeness: Comparing native and non-native judgments. Language Learning, 31(1), 17-30. https://doi.org/10.1111/j.14671770.1981.tb01370.x

Chen, R. (2001). Self-politeness: A proposal. Journal of Pragmatics, 33, 187-106. https://doi.org/10.1016/S0378-2166(99)00124-1

Gu, Y. G. (1990). Politeness phenomena in modern Chinese. Journal of Pragmatics, 14(2), 237-257. https://doi.org/10.1016/0378-2166(90)90082-O

Krasner, I. (1999). The role of culture in language teaching. Dialog on Language Instruction, 13(1-2), 79-88.

Ladegaard, H. J. (2004). Politeness in young children's speech: Context, peer group influence and pragmatic competence. Journal of Pragmatics, 36, 2003-2022. https://doi.org/10.1016/j.pragma.2003.11.008

Lee, Y. C. (2011). Comparison of politeness and acceptability perceptions of request strategies between Chinese learners of English and native English speakers. International Journal of Language Studies (IJLS), 5(3), 27-44. https://doi.org/10.5539/ass.v7n8p21

Liao, C. C., \& Bresnahan, M. I. (1996). A contrastive pragmatics study on American English and Mandarin refusal strategies. Language Sciences, 18(3), 703-727. https://doi.org/10.1016/S0388-0001(96)00043-5

Liu, J. (2001). Constructing chinese faces in American classrooms. Asian Journal of English Language Teachings, 11, 1-18.

Morand, D. A. (2003). Politeness and the clash of interaction orders in cross-cultural communication. Thunderbird International Business Review, 45, 521-540. Retrieved from http://dx.doi.org/10.1002/tie.10089

Xiao, H., \& Petraki, E. (2005). An understanding of Chinese students' difficulties in intercultural communication and its role in ELT. Retrieved January 2012 from http://www.usc.edu.au/NR/rdonlyres/C1506DC1

\section{Copyright Disclaimer}

Copyright for this article is retained by the author(s), with first publication rights granted to the journal.

This is an open-access article distributed under the terms and conditions of the Creative Commons Attribution license (http://creativecommons.org/licenses/by/3.0/). 